\title{
Synaptic differentiation: the role of agrin in the formation and maintenance of the neuromuscular junction
}

\author{
A.J. Denzer, D.M. Hauser, M. Gesemann, M.A. Ruegg \\ Department of Pharmacology, Biozentrum, University of Basel, Klingelbergstrasse 70, CH-4056 Basel, Switzerland
}

Received: 5 May 1997 / Accepted: 20 June 1997

\begin{abstract}
Upon arrival of a motor axon at the muscle fiber, signals released from its growth cone initiate the formation of a synapse. This process consists of two stages: arrest of axon growth at the target area and differentiation of pre- and postsynaptic cells at the site of nerve-muscle contact. Studies of regenerating neuromuscular junctions in vertebrates have revealed that important signals for the formation of this synapse are located in the synaptic basal lamina, and attempts to identify these signals have led to the isolation of agrin and other components. In this review, we discuss the evidence for the involvement of these molecules and their potential functional role in the formation and maintenance of the neuromuscular junction, with emphasis on agrin.
\end{abstract}

Key words: Neuromuscular junction - Acetylcholine receptor aggregation - Extracellular matrix - Synaptogenesis - Motor neuron - Myotube

\section{Introduction}

The capability of the brain to process information relies on a precise network of connections between neurons. The brain in an adult human, for example, consists of more than $10^{11}$ nerve cells, each connected with up to $10^{5}$ other cells. The intricate pattern of connections is formed during embryonic development when each differentiating neuron extends processes to its target cells to establish a special form of cell-cell contact, called the synapse. The processes or axons grow along specific pathways navigated by their leading tip, the growth cone. This

The work in our laboratory is supported by the Swiss National Science Foundation grant No. 31-33697.92, the Schweizerische Stiftung für die Erforschung der Muskelkrankheiten, the Schweizerische Rentenanstalt/Swiss Life, and the Sandoz-Stiftung

Correspondence to: M.A. Ruegg (Tel: +4161267 2246 or +4161 267 2213; Fax: +4161267 2208; E-mail: rueegg@ubaclu.unibas.ch) navigation machinery integrates the guidance information expressed by cells in the environment and converts this information into a directed out-growth of the elongating process (for a review, see Tessier-Lavigne and Goodman 1996). Axon growth is completed when the growth cone reaches the target cell and subsequently starts to form the synapse. The process of synapse formation follows axon growth and requires intercellular interactions between the growth cone and the target cell. Therefore, synapse formation can also be regarded as the ultimate step of axon guidance. Most of our current knowledge concerning synaptic development comes from studies of the vertebrate neuromuscular junction (NMJ), which serves as a suitable model and will be the focus of this review. The sequence of steps in the development of the NMJ includes arrest of motor axon growth at the target area and differentiation of pre- and postsynaptic elements (for a review, see Hall and Sanes 1993).

At the time when myoblasts fuse to form myotubes, each differentiating motor neuron in the spinal cord or brain stem extends an axon to a single muscle, where it branches and innervates several muscle fibers. Upon arrival at the target region, the growth cone of the axon is remodeled to become a highly specialized presynaptic nerve terminal containing vesicles filled with the neurotransmitter acetylcholine (ACh). The nerve terminal instructs the muscle fiber to form the postsynaptic apparatus. One of the earliest detectable signs of synaptic differentiation of the muscle fiber is the redistribution of preexisting, uniformly distributed acetylcholine receptors (AChRs) to the site of nerve-muscle contact (Anderson and Cohen 1977; Frank and Fischbach 1979; ZiskindConhaim et al. 1984). The accumulation of AChRs at synaptic sites is further increased by the up-regulation of AChR synthesis in the myonuclei lying underneath the NMJ and suppression of AChR gene expression in extra-synaptic regions (for a review Duclert and Changeux 1995). Several lines of evidence suggest that gene expression of AChRs at synaptic sites is regulated by trophic signals released from the nerve terminal (Usdin and Fischbach 1986), whereas down-regulation of AChR syn- 
thesis in non-synaptic regions is regulated by electrical activity (Goldman et al. 1988). As a result of all these processes, AChR density becomes as high as approximately $10^{4}$ molecules $/ \mu \mathrm{m}^{2}$ at the crests of specialized infoldings of the muscle membrane, called junctional folds (Salpeter and Harries 1983). Only about 10 AChRs $/ \mu m^{2}$ are found in extra-synaptic regions of the muscle fiber membrane (Salpeter et al. 1988). The cleft between the in-growing nerve terminal and the muscle fiber initially bears no recognizable basal lamina, but it soon, widens to about $50 \mathrm{~nm}$, and basal lamina components appear. Although the mature synaptic basal lamina is a continuum of the basal lamina surrounding the muscle fiber, it is structurally distinct (for a review, see Sanes 1995). Isoforms of collagen type IV and laminin, for example, are differentially distributed (Sanes et al. 1990), and other molecules, such as acetylcholinesterase (AChE; McMahan et al. 1978; Anglister and McMahan 1985) and neuregulin (NRG; Chu et al. 1995; Goodearl et al. 1995; Jo et al. 1995), are concentrated in the synaptic basal lamina.

After the initiation of synapse formation, embryonic muscle fibers of higher vertebrates are innervated by several motor neurons. The number of neuronal inputs is gradually reduced during early postnatal life until each muscle fiber is innervated by only one motor axon. The specific elimination of surplus motor inputs appears to be regulated by electrical activity and may also involve the removal of specific components from synaptic basal lamina (for a review, see Nguyen and Lichtman 1996).

In vivo studies on regenerating NMJ have demonstrated that the synaptic basal lamina contains molecules directing the differentiation of the nerve terminal and the muscle fiber (Sanes et al. 1978; Burden et al. 1979), this has led to the isolation of agrin (Nitkin et al. 1987). Addition of purified agrin to cultured muscle cells induces the aggregation of AChRs and many other proteins concentrated at the NMJ (Wallace 1989; Nitkin and Rothschild 1990). Over the past few years, many studies have provided further evidence for the central role of agrin in the formation of the nerve-muscle synapse. In the first two sections of this review, we shall summarize the evidence for the involvement of components of the synaptic basal lamina in pre- and postsynaptic differentiation of the developing neuromuscular synapse, with particular emphasis on agrin. In the last section, we shall focus on the potential role of agrin in the maintenance of neuromuscular structures.

\section{Presynaptic differentiation}

\section{Agrin}

The observation that agrin is present on the surface of myotubes prior to innervation (Reist et al. 1987; Godfrey et al. 1988; Lieth and Fallon 1993) and is concentrated in the synaptic basal lamina later in development prompted Campagna et al. (1995) to investigate the role of agrin in presynaptic differentiation. By using cell adhesion assays, they could show that ciliary ganglion neurons adhere better to agrin-expressing $\mathrm{CHO}$ cells than to non-transfected cells. Furthermore, neurites of ciliary ganglion neurons contacting such agrin-expressing cells stop growing and accumulate synaptotagmin at the site of contact (Campagna et al. 1995). Arrest of axon growth and the accumulation of synaptotagmin, a presynaptic vesicle protein, are well-characterized presynaptic processes during the course of synapse formation and are therefore used as markers for presynaptic differentiation. Based on these in vitro observations, agrin has been proposed to act as a retrograde signal that is released from muscle fibers and that promotes presynaptic specializations. Although the C-terminal half of agrin, which contains two conserved splice sites important for the regulation of the AChR-aggregating activity of agrin (see below and Fig. 1), is sufficient for presynaptic differentiation in vitro (Chang et al. 1997), inserts at these splice sites do not influence the response of ciliary ganglion neurons (Campagna et al. 1995). This finding is controversial as the growing motor axon itself secretes agrin at its tip and this consequently should inhibit axon growth. Nevertheless, agrin-deficient mice do not develop presynaptic nerve terminals (Gautam et al. 1996), a finding that is consistent with the proposed role for agrin in inducing presynaptic differentiation.

\section{Other candidate molecules}

Laminin-4, a laminin isoform, has also been suggested to be involved in signaling presynaptic differentiation (Hunter et al. 1989a, 1991; Porter et al. 1995). Because of its localization at the synaptic portion of the basal lamina of the muscle fiber, this laminin isoform was initially called s-laminin (Hunter et al. 1989b). Laminins are coiled-coil proteins assembled from three separate chains (Beck et al. 1990), called $\alpha, \beta$, and $\gamma$ (Burgeson et al. 1994). Over the past few years, ten different genes encoding laminin chains have been isolated and shown to give rise to many laminin isoforms (for a review, see Timpl 1996). Laminin-4, for example, is a trimer consisting of $\alpha 2, \beta 2$, and $\gamma 1$ chains. The $\beta 2$ chain makes laminin- 4 distinct from laminin-2, which is present in the extra-synaptic region of the basal lamina of the muscle fiber (Sanes et al. 1990; Schuler and Sorokin 1995). Since the peptide Leu-Arg-Glu (LRE) derived from the coiled-coil region of the $\beta 2$ chain is selectively adhesive to motor neurons and inhibits the out-growth of their neurites, the $\beta 2$ chain has been proposed to act as a retrograde stop signal for axon growth to promote presynaptic differentiation (Hunter et al. 1989a). Evidence against a primary inductive role of the $\beta 2$ chain in presynaptic differentiation is provided by the experiments performed by Brandenberger et al. (1996). Native chick laminin-4, which contains the $\beta 2$ chain, promotes rather than inhibits out-growth by chick motor neurons, and the effect of the LRE sequence of the $\beta 2$ chain depends on its structure. The LRE peptide in its native conformation, as found in laminin-4, does not inhibit neurite outgrowth (Brandenberger et al. 1996). This finding, together with the observation that $\beta 2$-deficient mice form NMJs (Noakes et al. 1995) and that the LRE sequence in the $\beta 2$ chain of rat and 


\section{CHICK AGRIN}

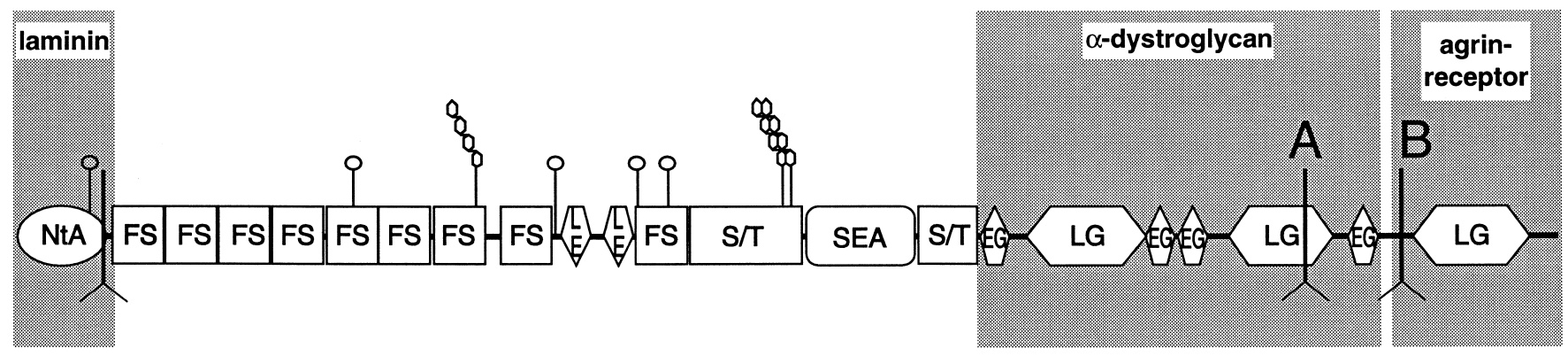

200 aa

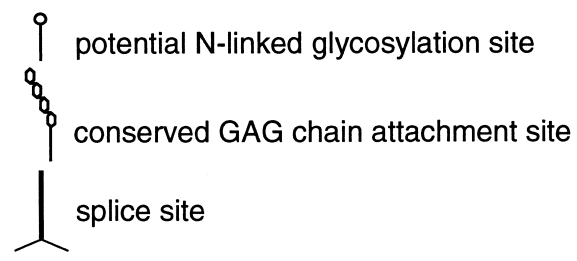

Fig. 1. Domain organization and binding sites in chick agrin. cDNAs encoding agrin have been cloned in rat, chick, and the marine ray (Rupp et al. 1991; Tsim et al. 1992; Smith et al. 1992). The deduced amino-acid sequence reveals a modular structure consisting of domains that are also present in other extracellular matrix molecules. Symbols and designations of domains illustrated are according to Bork and Bairoch (1995): NtA, N-terminal domain of agrin; $F S$, follistatin-like domain; $L E$, laminin epidermal growth factorlike domain; $S E A$, domain first found in sea urchin sperm protein, enterokinase, and agrin; $E G$, epidermal growth factor-like domain;

mouse (Hunter et al. 1991; Porter et al. 1995) is not conserved (Wewer et al. 1994), makes laminin-4 unlikely to act as a stop signal for in-growing motor axons.

\section{Postsynaptic differentiation}

Evidence for the instructive role of agrin in the assembly of the postsynaptic apparatus comes from AChR aggregation assays in vitro and, more recently, from the characterization of agrin-deficient mice. Agrin is varied by the insertion of small peptides at three splice sites (Fig. 1). In chick agrin, one site is located near the N-terminus (Tsen et al. 1995a; Denzer et al. 1995), and two sites (called A and B), are located within the C-terminus (Ruegg et al. 1992). The corresponding conserved C-terminal splice sites in rat are called y and $\mathrm{z}$ (Ferns et al. 1992). Assays on cultured myotubes have shown that inserts at the most C-terminal splice site B of agrin are crucial for AChR-clustering activity. Unlike isoforms carrying an insert at this site, agrin isoforms lacking an insert do not cluster AChRs (Ruegg et al. 1992; Ferns et al. 1992, 1993; Gesemann et al. 1995). Interestingly, agrin isoforms active in AChR aggregation are produced by motor neurons (Reist et al. 1992; Cohen and Godfrey 1992), whereas muscle cells express only agrin isoforms inactive in AChR aggregation.
$L G$, laminin G-like domain. In addition, the splice sites, the serine/threonine rich regions $(S / T)$, potential $\mathrm{N}$-linked glycosylation sites, and conserved glycosaminoglycan $(G A G)$ chain attachment sites are indicated. Heparan sulfate GAG side chains and other carbohydrates attached to the $225-\mathrm{kDa}$-core protein have been shown to be the reason for the high apparent $\mathrm{Mr}$ of $400-600 \mathrm{kDa}$ of agrin on SDS polyacrylamide gel electrophoresis (Tsen et al. 1995b; Denzer et al. 1995). Shaded rectangles represent the fragments sufficient for the binding to laminin, to $\alpha$-dystroglycan, and to the not yet identified signaling receptor of agrin

Agrin-mutant mice contain a targeted disruption of exons encoding splice site $\mathrm{z}$ of agrin (splice site $\mathrm{B}$ in chick; Gautam et al. 1996). As expected, homozygous mutant mice lack agrin variants active in AChR aggregation. For unknown reasons, they are also severe hypomorphs for the other splice variants. Mutant mice have grossly perturbed NMJs and die immediately before or at the time of birth, probably because of their failure to breathe. Although AChRs are synthesized at a normal level in these mutant mice, only few clusters are formed, and they associate with motor axon branches only rarely. The residual clustering of AChRs in these mice suggests that molecules distinct from agrin may also contribute to the aggregation of postsynaptic components (Kleiman and Reichardt 1997). In addition to the postsynaptic defects, motor axons do not stop growing and lack presynaptic specializations. The lack of functional NMJs demonstrates clearly that agrin is essential for synapses to form.

\section{Mechanism of agrin-mediated AChR aggregation}

So far, we have only fragmentary knowledge of the way in which neural agrin induces the formation of postsynaptic specializations in the muscle fiber. Several lines of evidence suggest that agrin mediates AChR aggregation by 
specific binding to a signaling receptor on the muscle cell membrane. First, agrin does not directly bind to AChRs (Godfrey et al. 1984; Ma et al. 1993), and AChR aggregates induced by agrin contain several other components of the postsynaptic apparatus (for a review, see Bowe and Fallon 1995). Second, AChR aggregation on cultured myotubes is preceded by tyrosine phosphorylation of their $\beta$-subunits (Wallace et al. 1991, Wallace 1995; Meier et al. 1996). When AChR $\beta$-subunit phosphorylation is inhibited by staurosporin, a non-selective antagonist of protein kinases, AChR clustering is also prevented (Wallace 1994; Ferns et al. 1996), suggesting that tyrosine kinases are involved in agrin-induced AChR aggregation.

A potential candidate for the agrin signaling receptor is a receptor-like tyrosine kinase, called MuSK (Jennings et al. 1993; Valenzuela et al. 1995) or Nsk2 (Ganju et al. 1995). This receptor tyrosine kinase is highly expressed in muscle fibers of newborn rats. Shortly after birth, the expression of MuSK is down-regulated and becomes restricted to the NMJ (Valenzuela et al. 1995). The phenotype of MuSK knock-out mice (DeChiara et al. 1996) closely resembles the phenotype of agrin-deficient mice. MuSK mutant mice also die perinatally. The motor axons do not form presynaptic specializations and they extend throughout the muscles without arborization of their nerve terminals. The postsynaptic deficiencies are even more severe than in agrin-mutant mice. MuSK knockout mice do not contain any AChR clusters or detectable amounts of AChE, although AChRs are expressed at normal levels. The synaptic expression of MuSK, together with the close resemblance of the phenotypes of mice mutant for MuSK and agrin, has led to the proposal that MuSK is the signaling receptor for agrin (DeChiara et al. 1996). As is typical of receptor tyrosine kinases, MuSK is a transmembrane protein with a large extracellular domain and a cytoplasmic tail that contains a region homologous to functional kinase domains. As indicative of activation of the receptor tyrosine kinase, MuSK becomes phosphorylated when stimulated with agrin isoforms active in AChR aggregation (Glass et al. 1996). Phosphorylation of MuSK can be detected after one minute (Glass et al. 1996) and precedes phosphorylation of the AChR $\beta$ subunit, suggesting that MuSK activation may be an early event of agrin-induced AChR aggregation. In conclusion, MuSK satisfies the expectations for the agrin signaling receptor to a large extent. However, all attempts to show a direct interaction between agrin and MuSK have failed. Glass et al. (1996) have hypothesized that direct binding cannot be detected because a third unknown component is required to form a signaling complex. This hypothesis is supported by the finding that MuSK can only be phosphorylated in differentiated muscle cells (Glass et al. 1996). Nevertheless, the lack of direct binding may alternatively indicate that another protein is the agrin signaling receptor, and MuSK is a downstream member of the signaling cascade.

$\alpha$-Dystroglycan is a peripheral membrane protein of muscle fibers and is concentrated at synaptic sites. As demonstrated by several laboratories independently, agrin binds to $\alpha$-dystroglycan (Bowe et al. 1994; Gee et al.
1994; Campanelli et al. 1994). Does $\alpha$-dystroglycan serve as the signal-transducing agrin receptor? For the following reasons, $\alpha$-dystroglycan is unlikely to be the signaling receptor. Both agrin isoforms active in AChR aggregation and inactive splice variants bind to $\alpha$-dystroglycan (Sugiyama et al. 1994). Binding of inactive agrin isoforms is of even higher affinity than that of active splice variants (Gesemann et al. 1996). Moreover, a 21-kDa Cterminal agrin fragment sufficient for AChR clustering on cultured myotubes (Gesemann et al. 1995) does not bind to purified $\alpha$-dystroglycan. However, specific binding of this agrin fragment is observed when it is added to cultured muscle cells (Gesemann et al. 1996). In conclusion, the function of agrin to induce postsynaptic differentiation requires the receptor tyrosine kinase MuSK and at least one additional component, distinct from $\alpha$-dystroglycan, which binds selectively to agrin isoforms active in AChR aggregation.

\section{The regulation of AChR synthesis}

In addition to the aggregation of preexisting AChRs, the induction of $\mathrm{AChR}$ gene expression in subsynaptic nuclei contributes to postsynaptic differentiation. AChR gene expression is nerve-dependent and characterized by the switch from AChR $\gamma$-subunit to $\varepsilon$-subunit expression leading to the adult type of $\mathrm{AChR}$ with the $\alpha 2 \beta \varepsilon \delta$ subunit composition (Brenner et al. 1990). At the regenerating NMJ of rodents, synaptic basal lamina is sufficient to regulate gene expression of the $\delta$-subunit to $\varepsilon$-subunit in myonuclei (Jo and Burden 1992; Brenner et al. 1992). Several lines of evidence suggest that AChR-inducing activity (ARIA) regulates this process. ARIA of chick is encoded by the same gene as are the Neu differentiation factor in rat, and heregulin and glial growth factors in human (Falls et al. 1993; Holmes et al. 1992; Wen et al. 1992; Marchionni et al. 1993). In addition, several isoforms arise by alternative mRNA splicing. The gene products are collectively called neuregulins (NRGs) and have been implicated in the differentiation and proliferation of various cells (for a review, see Gassmann and Lemke 1997). ARIA is synthesized by motor neurons early in development (Falls et al. 1993; Corfas et al. 1995) and is associated with the synaptic basal lamina of the NMJ (Jo et al. 1995; Goodearl et al. 1995; Loeb and Fischbach 1995). Addition of ARIA to cultured primary muscle cells causes an increase of mRNA encoding the AChR $\varepsilon$-subunit (Martinou et al. 1991; Chu et al. 1995). The way in which ARIA increases AChR gene expression is not entirely clear. There is evidence that several members of the epidermal growth factor receptor family, viz., ErbB-2, ErbB-3, and ErbB-4, are involved. These receptors become tyrosine-phosphorylated upon NRG binding and have been shown to be necessary for NRG signaling (Fig. 2; for a review, see Gassmann and Lemke 1997).

Although agrin does not increase AChR synthesis in cultured myotubes (Godfrey et al. 1984), recent results of Jones et al. (1996) indicate that substrate-bound agrin increases the amount of AChR $\varepsilon$-subunit mRNA in cul- 


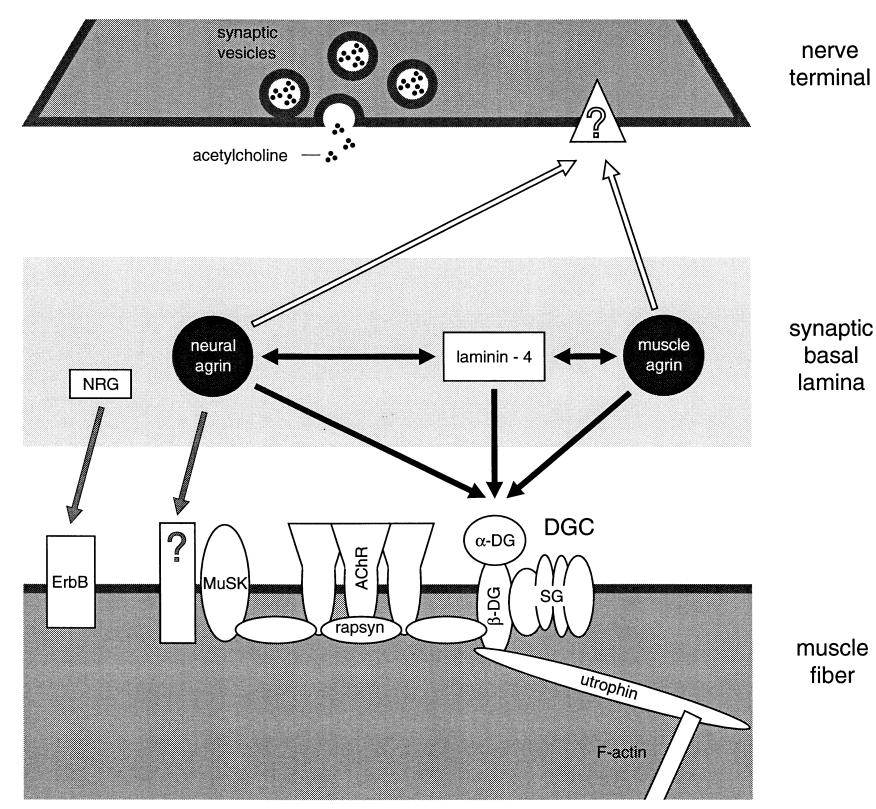

Fig. 2. Multiple interactions of the synaptic basal lamina components, agrin, laminin-4, and neuregulin. The interactions of these molecules implicated in presynaptic differentiation (open arrows), post-synaptic differentiation (shaded arrows), and maintenance of neuromuscular structures (black arrows) are shown. Neural and muscle agrin induce presynaptic differentiation via an unknown mechanism (open triangle with question mark). Unlike muscle agrin, neural agrin induces postsynaptic differentiation, such as the accumulation of acetylcholine receptors $(A C h R)$ in the muscle cell membrane, by the specific interaction with the not yet identified signaling receptor (open rectangle with question mark). This receptor is probably at the top of a signaling pathway, which includes the muscle-specific receptor tyrosine kinase $(M u S K)$. Gene expression of $A C h R$ subunits is induced in subsynaptic nuclei of the muscle fiber by the binding of neuregulin ( $N R G$; gene family including acetylcholine receptor inducing activity, called ARIA) to members of the $E r b B$ family. Furthermore, muscle and neural agrin are immobilized in the synaptic basal lamina through association with laminin4 and bind to $\alpha$-dystroglycan $(\alpha-D G)$, a peripheral member of the large dystrophin-glycoprotein complex $(D G C)$. This complex also contains the membrane spanning proteins, $\beta$-dystroglycan $(\beta-D G)$, the sarcoglycans $(S G)$, and the intracellular protein, utrophin. The $D G C$ links the synaptic basal lamina to the cytoskeleton (for a review, see Henry and Campbell 1996) and may represent the structure to which other post-synaptic proteins are associated. AChRs for example are thought to bind to the $D G C$ via the intracellular adapter protein rapsyn

tured muscle cells in the absence of nerve-supplied NRGs. This finding has subsequently been confirmed in vivo by expressing neural chick agrin at ectopic sites of denervated and innervated muscle fibers. In both cases, neural agrin induces AChR $\varepsilon$-subunit gene expression in the extra-synaptic region (Jones et al. 1997). These experiments show that nerve-derived ARIA is not required for the induction of AChR $\varepsilon$-subunit gene expression. However, it remains to be demonstrated whether the effect of agrin on AChR gene expression is direct or indirect. For example, agrin may cause the formation of an extracellular structure to which muscle-derived ARIA could bind and exert its effect on the muscle fiber.

\section{Maintenance of the NMJ}

After the initial establishment of synaptic connections, the specialized structure of the pre- and the postsynapse must be maintained throughout adulthood. Although the detailed mechanism of synaptic maintenance is not well understood, several lines of evidence suggest that synaptic basal lamina and agrin may be critically involved in this process.

On cultured myotubes, agrin-induced AChR clusters disappear when agrin is removed from the culture medium (Wallace 1989), indicating that AChR clusters in vitro need a continuous supply of agrin. In vivo, regeneration of synaptic structures depends on synaptic basal lamina, as shown by the classical experiments of McMahan and colleagues. In their experiments, synaptic basal lamina stimulated both pre- and postsynaptic cells to assemble a synaptic apparatus (Sanes et al. 1978; Burden et al. 1979). The maintenance of postsynaptic structures also seems to be dependent on synaptic basal lamina, as indicated by denervation experiments. If the rat soleus muscle is denervated, AChRs remain localized to former synaptic sites for more than 4 months. If, however, the muscle basal lamina, including its synaptic portion, is destroyed by proteolytic treatment, AChRs disperse in less than 2 days (Herczeg et al. 1995). Similarly, when muscle fibers of the frog cutaneous pectoris muscle are selectively removed and the motor innervation is left intact, presynaptic nerve terminals continue to release and recycle synaptic vesicles for up to 5 months, even in the absence of their target (Dunaevsky and Connor 1995).

These experiments indicate that synaptic basal lamina is sufficient to maintain the local specializations of the nerve terminal and the muscle fiber. Consistent with agrin's being responsible for this effect, agrin-like immunoreactivity remains associated with the synaptic basal lamina for at least 4 weeks after denervation (Reist et al. 1987). In summary, although most of these experiments do not directly show the role of agrin in maintaining synaptic specializations, they are all in agreement with it having such a role.

\section{Agrin binding to synaptic basal lamina via laminins}

The persistence of nerve-derived agrin in synaptic basal lamina can be accomplished by either its continued synthesis in motor neurons and/or its tight association with other components of the synaptic basal lamina. Although motor neurons express agrin transcripts throughout adulthood, the level of expression is considerably lower than that during embryonic development (e.g., Tsim et al. 1992; Smith et al. 1992; Stone and Nikolics 1995). Hence, the tight association of agrin with synaptic basal lamina must be the additional mechanism that maintains agrin within this structure. Support for such an association has been obtained by experiments showing that recombinant full-length chick agrin binds selectively to Matrigel, a commercial solubilized basal lamina. This binding requires the first 130 amino acids from the $\mathrm{N}$-terminus of agrin (Fig. 1; Denzer et al. 1995), a region that is 
not only necessary, but is also sufficient for the interaction with Matrigel (Denzer et al. 1997). Matrigel mainly contains collagen type IV and laminin, the two major constituents of cell basal lamina. Both molecules are thought to form independent networks by self assembly; these networks are linked by nidogen (for a review, see Yurchenco and O'Rear 1994) and form the scaffold of a basal lamina with which several other extracellular matrix proteins, such as perlecan, associate (for a review, see Timpl and Brown 1996). By assaying binding to individual components of Matrigel, laminin-1 (the laminin isoform found in this preparation) has been identified as the binding partner of agrin. The binding is of high affinity with a dissociation constant of approximately $5 \mathrm{nM}$. In addition, agrin also binds to laminin-2 and laminin-4 (Denzer et al. 1997), the two predominant laminin isoforms expressed by muscle fibers (Sanes et al. 1990; Schuler and Sorokin 1995). The binding of agrin to laminin-4, which has been localized to the synaptic region of the basal lamina of the muscle fiber (Hunter et al. 1989b), suggests that this interaction is the probable basis for the stable association of agrin with the synaptic basal lamina in vivo.

\section{Agrin removal during synapse elimination}

In the muscle of adult vertebrates, each muscle fiber is innervated by a single motor neuron. At birth, however, muscle fibers are innervated by multiple motor axons. Over approximately the first two postnatal weeks, in a process called synapse elimination, all but one contact to the motor neurons is given up. Elimination of synapses is based on competition between individual inputs, resulting in the maintenance of the most active or effective ones at the expense of the least active. Several lines of evidence indicate that this process requires electrical activity and is initiated by the selective loss of AChRs in the postsynaptic membrane (Rich and Lichtman 1989; Balice-Gordon et al. 1993). This loss then activates a feedback mechanism that causes the progressive retraction of the overlying nerve terminal (Balice-Gordon and Lichtman 1994; Colman et al. 1997).

In innervated muscle, motor-neuron-derived agrin, when deposited at non-synaptic regions, induces the formation of postsynaptic specializations in the absence of the nerve (Cohen et al. 1997; Jones et al. 1997; Meier et al. 1997). Consequently, removal of AChRs from postsynaptic sites during synapse elimination requires the selective inactivation/removal of neural agrin from synaptic basal lamina. Indeed, agrin-like immunoreactivity is absent from abandoned synaptic basal lamina of frog NMJs (Werle and Sojka 1996). The removal of agrin from these sites is rapid, and no agrin-like immunoreactivity is observed after only 7 days (Werle and Sojka 1996). These experiments suggest that electrically active muscle fibers actively remove agrin from synaptic sites, in contrast to denervated muscle, where agrin remains attached to synaptic basal lamina for several weeks (Reist et al. 1987). In this context, it is interesting to note that the protease thrombin and its inhibitor, protease nexin 1 , have been implicated in the process of synapse elimination (Liu et al. 1994; Zoubine et al. 1996). However, it remains to be seen whether agrin is a substrate for thrombin.

\section{A potential role of agrin in the stabilization of junctional AChR clusters}

After synapse elimination is complete, the remaining AChRs must be tightly anchored to synaptic sites. What are the mechanisms that are involved in this process? One way of maintaining these molecules at the site of nerve-muscle contacts after their initial localization would be to stabilize their association with components of the synaptic basal lamina. Neural agrin, which is incorporated into the synaptic basal lamina binds directly to at least two distinct proteins expressed by the muscle fiber, the agrin signaling receptor and $\alpha$-dystroglycan (Fig. 1). As summarized above, binding of agrin to $\alpha$-dystroglycan is not necessary for the induction of synaptic specializations. Nevertheless, this interaction may have a more structural function at the NMJ, since $\alpha$-dystroglycan is associated with the cell membrane by its binding to the transmembrane protein $\beta$-dystroglycan. Both components are members of the large dystrophin-glycoprotein complex (DGC; Fig. 2). This complex connects the basal lamina of the muscle fiber with the underlying cytoskeleton by the intracellular interaction of $\beta$-dystroglycan with actin-filament-linked dystrophin at extra-synaptic regions (Hemmings et al. 1992) and utrophin at synaptic regions (Jung et al. 1995). The DGC is also attached to the basal lamina of the muscle fiber by the binding of $\alpha$-dystroglycan to laminin (Ibraghimov-Beskrovnaya et al. 1992). This DGC-mediated linkage has been proposed to provide mechanical stability during muscle contraction, because mutations in the gene encoding the $\alpha 2$ chain of muscle laminin isoforms or members of the DGC lead to several diseases of skeletal muscle (for a review, see Campbell 1995). The binding of agrin to $\alpha$-dystroglycan may therefore also have such a stabilizing function at the NMJ, as both the DGC and agrin are concentrated at this site. The finding that AChRs are linked to the DGC via rapsyn (Fig. 2; Apel et al. 1995), an intracellular protein exclusively found at the NMJ, suggests that the binding of agrin to $\alpha$-dystroglycan may be a way of indirectly attaching AChRs and perhaps additional post-synaptic components to the synaptic region of the basal lamina of the muscle fiber. In conclusion, agrin may have a structural function at the NMJ, in addition to its role in the induction of synaptic differentiation.

\section{Conclusions}

A major reason for studying NMJ development is to learn more about mechanisms that may also be used in the formation of other synapses. The recent discovery of some of the molecular mechanisms involved in the formation of interneuronal synapses supports the view that the NMJ is a good model for understanding the basic mechanisms of synapse formation. Our current knowledge as 
summarized in this review, clearly shows that agrin plays a key role in the development of the NMJ. As agrin transcripts are expressed in the brain (e.g., O'Connor et al. 1994) and as agrin-like immunoreactivity is also found at synaptic sites in the chick retina (Mann and Kröger 1996), future studies should focus on whether agrin plays a role in the formation of interneuronal synapses.

Acknowledgements. We should like to thank Drs. Thomas Meier and Graham Jones for their helpful comments on this manuscript.

\section{References}

Anderson MJ, Cohen MW (1977) Nerve-induced and spontaneous redistribution of acetylcholine receptros on cultured muscle cells. J Physiol (Lond) 268:757-773

Anglister L, McMahan UJ (1985) Basal lamina directs acetylcholinesterase accumulation at the synaptic sites in regenerating muscle. J Cell Biol 101:735-743

Apel ED, Roberds SL, Campbell KP, Merlie JP (1995) Rapsyn may function as a link between the acetylcholine receptor and the agrin-binding dystrophin-associated glycoprotein complex. Neuron 15:115-126

Balice-Gordon RJ, Lichtman JW (1994) Long-term synapse loss induced by focal blockade of postsynaptic receptors. Nature 372:519-524

Balice-Gordon RJ, Chua CK, Nelson CC, Lichtman JW (1993) Gradual loss of synaptic cartels precedes axon withdrawal at developing neuromuscular junctions. Neuron 11:801-815

Beck K, Hunter I, Engel J (1990) Structure and function of laminin: anatomy of a multidomain glycoprotein. FASEB J 4:148-160

Bork P, Bairoch A (1995) Extracellular protein modules. Trends Biochem Sci 20:104-105, 02 (Supplement)

Bowe MA, Fallon JR (1995) The role of agrin in synapse formation. Annu Rev Neurosci 18:443-462

Bowe MA, Deyst KA, Leszyk JD, Fallon JR (1994) Identification and purification of an agrin receptor from Torpedo postsynaptic membranes: a heteromeric complex related to the dystroglycans. Neuron 12:1173-1180

Brandenberger R, Kammerer RA, Engel J, Chiquet M (1996) Native chick laminin- 4 containing the $\beta 2$ chain (s-laminin) promotes motor axon growth. J Cell Biol 135:1583-1592

Brenner HR, Witzemann V, Sakmann B (1990) Imprinting of acetylcholine receptor messenger RNA accumulation in mammalian neuromuscular synapses. Nature 344:544-547

Brenner HR, Herczeg A, Slater CR (1992) Synapse-specific expression of acetylcholine receptor genes and their products at original synaptic sites in rat soleus muscle fibers regenerating in the absence of innervation. Development 116:41-53

Burden SJ, Sargent PB, McMahan UJ (1979) Acetylcholine receptors in regenerating muscle accumulate at original synaptic sites in the absence of the nerve. J Cell Biol 82:412-425

Burgeson RE, Chiquet M, Deutzmann R, Ekblom P, Engel J, Kleinman H, Martin GR, Meneguzzi G, Paulsson M, Sanes J, Timpl R, Tryggvason K, Yamada Y, Yurchenco PD (1994) A new nomenclature for the laminins. Matrix Biol 14:209-211

Campagna JA, Rüegg MA, Bixby JL (1995) Agrin is a differentiation-inducing "stop signal" for motoneurons in vitro. Neuron 15:1365-1374

Campanelli JT, Roberds SL, Campbell KP, Scheller RH (1994) A role for dystrophin-associated glycoproteins and utrophin in agrin-induced AChR clustering. Cell 77:663-674

Campbell KP (1995) Three muscular dystrophies: loss of cytoskeleton-extracellular matrix linkage. Cell 80:675-679

Chang D, Woo JS, Campanelli J, Scheller RH, Ignatius MJ (1997) Agrin inhibits neurite outgrowth but promotes attachment of embryonic motor and sensory neurons. Dev Biol 181:21-35
Chu GC, Moscoso LM, Sliwkowski MX, Merlie JP (1995) Regulation of the acetylcholine receptor epsilon subunit gene by recombinant ARIA: an in vitro model for transynaptic gene regulation. Neuron 14:329-339

Cohen MW, Godfrey EW (1992) Early appearance of and neuronal contribution to agrin-like molecules at embryonic frog nervemuscle synapses formed in culture. J Neurosci 12:2982-2992

Cohen I, Rimer M, Lomo T, McMahan UJ (1997) Agrin-induced postsynaptic apparatus in skeletal muscle fibers in vivo. Mol Cell Neurosci 9:(in press)

Colman H, Nabekura J, Lichtman JW (1997) Alterations in synaptic strength preceding axon withdrawal. Science 275:356-361

Corfas G, Rosen KM, Aratake H, Krauss R, Fischbach GD (1995) Differential expression of ARIA isoforms in the rat brain. Neuron 14:103-115

DeChiara TM, Bowen DC, Valenzuela DM, Simmons MV, Poueymirou WT, Thomas S, Kinetz E, Compton DL, Rojas E, Park JS, Smith C, DiStefano PS, Glass DJ, Burden SJ, Yancopoulos GD (1996) The receptor tyrosine kinase MuSK is required for neuromuscular junction formation in vivo. Cell 85: $501-512$

Denzer AJ, Gesemann M, Schumacher B, Ruegg MA (1995) An amino-terminal extension is required for the secretion of chick agrin and its binding to extracellular matrix. J Cell Biol 131:1547-1560

Denzer AJ, Brandenberger R, Gesemann M, Chiquet M, Ruegg MA (1997) Agrin binds to the nerve-muscle basal lamina via laminin. J Cell Biol 137:671-683

Duclert A, Changeux JP (1995) Acetylcholine receptor gene expression at the developing neuromuscular junction. Physiol Rev 75:339-368

Dunaevsky A, Connor EA (1995) Long-term maintenance of presynaptic function in the absence of target muscle fibers. J Neurosci 15:6137-6144

Falls DL, Rosen KM, Corfas G, Lane WS, Fischbach GD (1993) ARIA, a protein that stimulates acetylcholine receptor synthesis, is a member of the neu ligand family. Cell 72:801-815

Ferns M, Hoch W, Campanelli JT, Rupp F, Hall ZW, Scheller RH (1992) RNA splicing regulates agrin-mediated acetylcholine receptor clustering activity on cultured myotubes. Neuron 8 : 1079-1086

Ferns MJ, Campanelli JT, Hoch W, Scheller RH, Hall Z (1993) The ability of agrin to cluster AChRs depends on alternative splicing and on cell surface proteoglycans. Neuron 11:491-502

Ferns M, Deiner M, Hall Z (1996) Agrin-induced acetylcholine receptor clustering in mammalian muscle requires tyrosine phosphorylation. J Cell Biol 132:937-944

Frank E, Fischbach GD (1979) Early events in neuromuscular junction formation in vitro: induction of acetylcholine receptor clusters in the postsynaptic membrane and morphology of newly formed synapses. J Cell Biol 83:143-158

Ganju P, Walls E, Brennan J, Reith AD (1995) Cloning and developmental expression of Nsk2, a novel receptor tyrosine kinase implicated in skeletal myogenesis. Oncogene 11:281-290

Gassmann M, Lemke G (1997) Neuregulins and neuregulin receptors in neural development. Curr Opin Neurobiol 7:87-92

Gautam M, Noakes PG, Moscoso L, Rupp F, Scheller RH, Merlie JP, Sanes JR (1996) Defective neuromuscular synaptogenesis in agrin-deficient mutant mice. Cell 85:525-535

Gee SH, Montanaro F, Lindenbaum MH, Carbonetto S (1994) Dystroglycan- $\alpha$, a dystrophin-associated glycoprotein, is a functional agrin receptor. Cell 77:675-686

Gesemann M, Denzer AJ, Ruegg MA (1995) Acetylcholine receptor-aggregating activity of agrin isoforms and mapping of the active site. J Cell Biol 128:625-636

Gesemann M, Cavalli V, Denzer AJ, Brancaccio A, Schumacher B, Ruegg MA (1996) Alternative splicing of agrin alters its binding to heparin, dystroglycan, and the putative agrin receptor. Neuron 16:755-767

Glass DJ, Bowen DC, Stitt TN, Radziejewski C, Bruno J, Ryan TE, Gies DR, Shah S, Mattsson K, Burden SJ, DiStefano PS, 
Valenzuela DM, DeChiara TM, Yancopoulos GD (1996) Agrin acts via a MuSK receptor complex. Cell 85:513-523

Godfrey EW, Nitkin RM, Wallace BG, Rubin LL, McMahan UJ (1984) Components of Torpedo electric organ and muscle that cause aggregation of acetylcholine receptors on cultured muscle cells. J Cell Biol 99:615-627

Godfrey EW, Siebenlist RE, Wallskog PA, Walters LM, Bolender DL, Yorde DE (1988) Basal lamina components are concentrated in premuscle masses and at early acetylcholine receptor clusters in chick embryo hindlimb muscles. Dev Biol 130: $471-486$

Goldman D, Brenner HR, Heineman S (1988) Acetylcholine receptor alpha-, beta-, gamma, and delta-subunit mRNA levels are regulated by muscle activity. Neuron 1:329-333

Goodearl ADJ, Yee AG, Sandrock AW Jr, Corfas G, Fischbach GD (1995) ARIA is concentrated in the synaptic basal lamina of the developing chick neuromuscular junction. J Cell Biol 130: $1423-1434$

Hall ZW, Sanes JR (1993) Synaptic structure and development: the neuromuscular junction. Cell 10 (Suppl):99-121

Hemmings L, Kuhlman PA, Critchley DR (1992) Analysis of the actin-binding domain of alpha-actinin by mutagenesis and demonstration that dystrophin contains a functionally homologous domain. J Cell Biol 116:1369-1380

Henry MD, Campbell KP (1996) Dystroglycan: an extracellular matrix receptor linked to the cytoskeleton. Curr Opin Cell Biol 8:625-631

Herczeg A, Jones G, Brenner HR (1995) Involvement of extracellular matrix in acetylcholine receptor $\varepsilon$-subunit gene expression at the rat neuromuscular junction. Neurosci Lett 193:33-36

Holmes WE, Sliwkowski MX, Akita RW, Henzel WJ, Lee J, Park JW, Yansura D, Abadi N, Raab H, Lewis GD (1992) Identification of heregulin, a specific activator of p185erbB2. Science 256: $1205-1210$

Hunter DD, Porter BE, Bulock JW, Adams SP, Merlie JP, Sanes JR (1989a) Primary sequence of a motor neuron-selective adhesive site in the synaptic basal lamina protein S-laminin. Cell 59:905913

Hunter DD, Shah V, Merlie JP, Sanes JR (1989b) A laminin-like adhesive protein concentrated in the synaptic cleft of the neuromuscular junction. Nature 338:229-234

Hunter DD, Cashman N, Morris VR, Bulock JW, Adams SP, Sanes JR (1991) An LRE (leucine-arginine-glutamate)-dependent mechanism for adhesion of neurons to S-laminin. J Neurosci 11:3960-3971

Ibraghimov-Beskrovnaya O, Ervasti JM, Leveille CJ, Slaughter CA, Sernett SW, Campbell KP (1992) Primary structure of dystrophin-associated glycoproteins linking dystrophin to the extracellular matrix. Nature 355:696-702

Jennings CG, Dyer SM, Burden SJ (1993) Muscle-specific trk-related receptor with a kringle domain defines a distinct class of receptor tyrosine kinases. Proc Natl Acad Sci USA 90:2895-2899

Jo SA, Burden SJ (1992) Synaptic basal lamina contains a signal for synapse-specific transcription. Development 115:673-680

Jo SA, Zhu X, Marchionni MA, Burden SJ (1995) Neuregulins are concentrated at nerve-muscle synapses and activate ACh-receptor gene expression. Nature 373:158-161

Jones G, Herczeg A, Ruegg MA, Lichtsteiner M, Kröger S, Brenner HR (1996) Substrate-bound agrin induces expression of acetylcholine receptor $\varepsilon$-subunit gene in cultured mammalian muscle cells. Proc Natl Acad Sci USA 93:5985-5990

Jones G, Meier T, Lichtsteiner M, Witzemann V, Sakmann B, Brenner HR (1997) Induction by agrin of ectopic and functional postsynaptic-like membrane in innervated muscle. Proc Natl Acad Sci USA 94:2654-2659

Jung D, Yang B, Meyer J, Chamberlain JS, Campbell KP (1995) Identification and characterization of the dystrophin anchoring site on $\beta$-dystroglycan. J Biol Chem 270:27305-27310

Kleiman RJ, Reichardt LF (1996) Testing the agrin hypothesis. Cell 85:461-464
Lieth E, Fallon JR (1993) Muscle agrin: neural regulation and localization at nerve-induced acetylcholine receptor clusters. J Neurosci 13:2509-2514

Liu Y, Fields RD, Festoff BW, Nelson PG (1994) Proteolytic action of thrombin is required for electrical activity-dependent synapse reduction. Proc Natl Acad Sci USA 91:10300-10304

Loeb JA, Fischbach GD (1995) ARIA can be released from extracellular matrix through cleavage of a heparin-binding domain. J Cell Biol 130:127-135

Ma J, Nastuk MA, McKechnie BA, Fallon JR (1993) The agrin receptor. Localization in the postsynaptic membrane, interaction with agrin, and relationship to the acetylcholine receptor. J Biol Chem 268:25108-25117

Mann S, Kröger S (1996) Agrin is synthesized by retinal cells and colocalizes with gephyrin. Mol Cell Neurosci 8:1-13

Marchionni MA, Goodearl AD, Chen MS, Bermingham-McDonogh O, Kirk C, Hendricks M, Danehy F, Misumi D, Sudhalter J, Kobayashi K (1993) Glial growth factors are alternatively spliced erbB2 ligands expressed in the nervous system. Nature 362:312-318

Martinou JC, Falls DL, Fischbach GD, Merlie JP (1991) Acetylcholine receptor-inducing activity stimulates expression of the epsilon-subunit gene of the muscle acetylcholine receptor. Proc Natl Acad Sci USA 88:7669-7673

McMahan UJ, Sanes JR, Marshall LM (1978) Cholinesterase is associated with the basal lamina at the neuromuscular junction. Nature 271:172-174

Meier T, Gesemann M, Cavalli V, Ruegg MA, Wallace BG (1996) AChR phosphorylation and aggregation induced by an agrin fragment that lacks the binding domain for alpha-dystroglycan. EMBO J 15:2625-2631

Meier T, Hauser DM, Chiquet M, Landmann L, Ruegg MA, Brenner HR (1997) Neural agrin induces ectopic postsynaptic specializations in innervated muscle fibers. J Neurosci (in press)

Nguyen QT, Lichtman JW (1996) Mechanism of synapse disassembly at the developing neuromuscular junction. Curr Opin Neurobiol 6:104-112

Nitkin RM, Rothschild TC (1990) Agrin-induced reorganization of extracellular matrix components on cultured myotubes: relationship to AChR aggregation. J Cell Biol 111:1161-1170

Nitkin RM, Smith MA, Magill C, Fallon JR, Yao Y-MM, Wallace BG, McMahan UJ (1987) Identification of agrin, a synaptic organizing protein from Torpedo electric organ. J Cell Biol 105:2471-2478

Noakes PG, Gautam M, Mudd J, Sanes JR, Merlie JP (1995) Aberrant differentiation of neuromuscular junctions in mice lacking s-laminin/laminin $\beta 2$. Nature 374:258-262

O'Connor LT, Lauterborn JC, Gall CM, Smith MA (1994) Localization and alternative splicing of agrin mRNA in adult rat brain: transcripts encoding isoforms that aggregate acetylcholine receptors are not restricted to cholinergic regions. J Neurosci 14:1141-1152

Porter BE, Weis J, Sanes JR (1995) A motoneuron-selective stop signal in the synaptic protein S-laminin. Neuron 14:549-559

Reist NE, Magill C, McMahan UJ (1987) Agrin-like molecules at synaptic sites in normal, denervated, and damaged skeletal muscles. J Cell Biol 105:2457-2469

Reist NE, Werle MJ, McMahan UJ (1992) Agrin released by motor neurons induces the aggregation of acetylcholine receptors at neuromuscular junctions. Neuron 8:865-868

Rich MM, Lichtman JW (1989) In vivo visualization of pre- and postsynaptic changes during synapse elimination in reinnervated mouse muscle. J Neurosci 9:1781-1805

Ruegg MA, Tsim KW, Horton SE, Kröger S, Escher G, Gensch EM, McMahan UJ (1992) The agrin gene codes for a family of basal lamina proteins that differ in function and distribution. Neuron 8:691-699

Rupp F, Payan DG, Magill-Solc C, Cowan DM, Scheller RH (1991) Structure and expression of a rat agrin. Neuron 6:811-823 
Salpeter MM, Harris R (1983) Distribution and turnover rate of acetylcholine receptors throughout the junction folds at a vertebrate neuromuscular junction. J Cell Biol 96:1781-1785

Salpeter MM, Marchaterre M, Harris R (1988) Distribution of extrajunctional acetylcholine receptors on a vertebrate muscle: evaluated by using scanning electron microscope autoradiographic procedure. J Cell Biol 106:2087-2093

Sanes JR (1995) The synaptic cleft of the neuromuscular junction. Semin Dev Biol 6:163-173

Sanes JR, Marshall LM, McMahan UJ (1978) Reinnervation of muscle fiber basal lamina after removal of myofibers. Differentiation of regenerating axons at original synaptic sites. J Cell Biol 78:176-198

Sanes JR, Engvall E, Butkowski R, Hunter DD (1990) Molecular heterogeneity of basal laminae: isoforms of laminin and collagen IV at the neuromuscular junction and elsewhere. J Cell Biol 111:1685-1699

Schuler F, Sorokin LM (1995) Expression of laminin isoforms in mouse myogenic cells in vitro and in vivo. J Cell Sci 108: 3795-3805

Smith MA, Magill-Solc C, Rupp F, Yao YM, Schilling JW, Snow P, McMahan UJ (1992) Isolation and characterization of an agrin homologue in the marine ray. Mol Cell Neurosci 3:406-417

Stone DM, Nikolics K (1995) Tissue- and age-specific expression patterns of alternatively spliced agrin mRNA transcripts in embryonic rat suggest novel developmental roles. J Neurosci 15:6767-6778

Sugiyama J, Bowen DC, Hall ZW (1994) Dystroglycan binds nerve and muscle agrin. Neuron 13:103-115

Tessier-Lavigne M, Goodman CS (1996) The molecular biology of axon guidance. Science 274:1123-1133

Timpl R (1996) Macromolecular organization of basement membranes. Curr Opin Cell Biol 8:618-624

Timpl R, Brown JC (1996) Supramolecular assembly of basement membranes. Bioessays 18:123-131

Tsen G, Napier A, Halfter W, Cole GJ (1995a) Identification of a novel alternatively spliced agrin mRNA that is preferentially expressed in non-neuronal cells. J Biol Chem 270:1593415937

Tsen G, Halfter W, Kroger S, Cole GJ (1995b) Agrin is a heparan sulfate proteoglycan. J Biol Chem 270: 3392-3399

Tsim KWK, Ruegg MA, Escher G, Kröger S, McMahan UJ (1992) cDNA that encodes active agrin. Neuron 8:677-689
Usdin TB, Fischbach GD (1986) Purification and characterization of a polypeptide from chick brain that promotes the accumulation of acetylcholine receptors in chick myotubes. J Cell Biol 103:493-507

Valenzuela DM, Stitt TN, DiStefano PS, Rojas E, Mattsson K, Compton DL, Nunez L, Park JS, Stark JL, Gies DR, Thomas S, Le BMM, Fernald AA, Copeland NG, Jenkins NA, Burden SJ, Glass DJ, Yancopoulos GD (1995) Receptor tyrosine kinase specific for the skeletal muscle lineage: expression in embryonic muscle, at the neuromuscular junction, and after injury. Neuron 15:573-584

Wallace BG (1989) Agrin-induced specializations contain cytoplasmic, membrane, and extracellular matrix-associated components of the postsynaptic apparatus. J Neurosci 9:1294-1302

Wallace BG (1994) Staurosporine inhibits agrin-induced acetylcholine receptor phosphorylation and aggregation. J Cell Biol 125:661-668

Wallace BG (1995) Regulation of the interaction of nicotinic acetylcholine receptors with the cytoskeleton by agrin-activated protein tyrosine kinase. J Cell Biol 128:1121-1129

Wallace BG, Qu Z, Huganir RL (1991) Agrin induces phosphorylation of the nicotinic acetylcholine receptor. Neuron 6:869-878

Wen D, Peles E, Cupples R, Suggs SV, Bacus SS, Luo Y, Trail G, Hu S, Silbiger SM, Levy RB (1992) Neu differentiation factor: a transmembrane glycoprotein containing an EGF domain and an immunoglobulin homology unit. Cell 69:559-572

Werle MJ, Sojka AM (1996) Anti-agrin staining is absent at abandoned synaptic sites of frog neuromuscular junctions. J Neurobiol 30:293-302

Wewer UM, Gerecke DR, Durkin ME, Kurtz KS, Mattei MG, Champliaud MF, Burgeson RE, Albrechtsen R (1994) Human beta 2 chain of laminin (formerly $\mathrm{S}$ chain): cDNA cloning, chromosomal localization, and expression in carcinomas. Genomics 24:243-252

Yurchenco PD, O'Rear JJ (1994) Basal lamina assembly. Curr Opin Cell Biol 6:674-681

Ziskind-Conhaim L, Geffen I, Hall ZW (1984). Redistribution of acetylcholine receptors on developing rat myotubes. J Neurosci 4:2346-2349

Zoubine MN, Ma JY, Smirnova IV, Citron BA, Festoff BW (1996) A molecular mechanism for synapse elimination: novel inhibition of locally generated thrombin delays synapse loss in neonatal mouse muscle. Dev Biol 179:447-457 